\title{
Studi Perbandingan Hasil Belajar Fisika Yang Diajar Menggunakan Model Course Review Horay (CRH) dan Model Number Head Together (NHT) pada Siswa SMA Negeri 11 Kendari
}

\author{
Jamarudin $^{1}$; Zainuddin ${ }^{2}$; Abdul Kadir ${ }^{2}$; La Isa ${ }^{2}$ \\ 1) Alumni Prodi Tadris Fisika, Fakultas Tarbiyah dan Ilmu Keguruan (FTIK), Institut Agama Islam Negeri \\ (IAIN Kendari) \\ ${ }^{2)}$ Dosen FTIK, IAIN Kendari \\ Email Korespondensi: zainuddin.zain.fis@gmail.com
}

\begin{abstract}
This research is an experimental study with a Pre-test-Post-test Kontrol Group Design. The purpose of this study is (1) Describe the physics learning outcomes of students taught with the CRH model and the NHT model in SMA Negeri 11 Kendari. (3) Knowing the differences in student physics learning outcomes before and after using the CRH model (4) Knowing the differences in student physics learning outcomes after using the CRH model and the NHT model. The results showed: (1) The cognitive learning outcomes of students who were taught using the CRH and NHT models experienced an increase in learning outcomes the average value in the experimental class before using the CRH model was 55.87 and the value after using the CRH model was 76.37, while the value the average in the control class before using the NHT model is 54.73 and the value after using the NHT model is 84.19; (2) There are differences in learning outcomes before and after using the CRH model in the experimental class with a significant level of $5 \% t_{\text {count }}>t_{\text {table }}(9,400>2.0425)$; (3) There are differences in learning outcomes after using the CRH model in the experimental class and after using the NHT model in the control class as evidenced by $t_{\text {count }}>t_{\text {table }}(2.661>2.0488)$. Thus the cognitive learning outcomes of students taught with the NHT model are more effective than the learning outcomes of students taught with the CRH model.
\end{abstract}

Keywords: Physics Learning Outcomes, CRH Model and NHT Model.

\section{ABSTRAK}

Penelitian ini merupakan penelitian eksperimen dengan desain Pre-test-Post-test Control Group Design. Tujuan penelitian ini adalah (1) Mendeskripsikan hasil belajar fisika siswa yang diajar dengan model CRH dan model NHT di SMA Negeri 11 Kendari. (2) Mengetahui perbedaan hasil belajar fisika siswa sebelum diajar menggunakan model CRH dan NHT (3) Mengetahui perbedaan hasil belajar fisika siswa sesudah menggunakan model CRH dan model NHT. Hasil penelitian menunjukkan: (1) Hasilbelajar kognitif siswa yang diajar menggunakan model CRH dan NHT mengalami peningkatan hasil belajar yakni nilai rata-rata pada kelas eksprimen sebelum menggunakan model CRH yaitu 55,87 dan nilai sesudah menggunakan model CRH yaitu76,37,sedangkan nilai rata-rata pada kelas kontrol sebelum menggunakan model NHT yaitu 54,73 dan nilai setelah menggunakan model NHT yaitu 84,19; (2) Terdapat perbedaan hasil belajar sebelum dan sesudah menggunakan model $\mathrm{CRH}$ pada kelas eksperimen dengan taraf signifikan $5 \%$ harga $\mathrm{t}_{\text {hitung }}>\mathrm{t}_{\text {tabel }}(9,400>$ 2,0425); (3) Terdapat perbedaan hasil belajar setelah menggunakan model CRH pada kelas eksperimen dan setelah menggunakan model NHT pada kelas kontrol dibuktikan dengan $t_{\text {hitung }}>t_{\text {tabel }}(2,661>2,0488)$. Dengan demikian hasil belajar kognitif siswa yang diajar dengan model NHT lebih efektif dari pada hasil belajar siswa yang diajar dengan model CRH.

Kata Kunci: Hasil Belajar Fisika, Model CRH dan Model NHT

\section{PENDAHULUAN}

Pendidikan adalah bimbingan yang diberikan oleh orang dewasa kepada perkembangan anak untuk mencapai kedewasaan yang bertujuan agar anak cakap dalam melaksanakan tugas hidup sendiri tanpa bantuan orang lain, dengan kata lain membimbing anak mencapai kedewasaan (Engkoswara \& Komariah, 2011).

Fisika merupakan ilmu pengetahuan yang mendasar, karena fisika berkaitan dengan perilaku dan struktur benda. Tujuan utama sains termasuk fisika merupkan usaha untuk mencari keteraturan dalam pengamatan manusia pada alam sekitar (Giancoli, 2014). Hukum Newton adalah salah satu materi fisika yang masih sangat sulit difahami oleh sebagian besar siswa. Kesulitan tersebut disebabkan oleh konsep dari materi yang sangat banyak. Salah satu cara untuk menanggulangi kesulitan tersebut adalah menanamkan rasa senang belajar fisika, misalnya dengan menerapkan model pembelajaran yang menarik dan interaktif agar siswa lebih semangat dan antusias untuk mengikuti proses pembelajaran meskipun dengan materi yang sulit 
CRH (Course Review Horay) adalah salah satu model pembelajaran yang dapat menciptakan suasana kelas menjadi menyenangkan karena setiap siswa yang mampu menjawab dengan benar akan berteriak "hore!" atau yel-yel lain yang disukai. Metode ini dapat membantu siswa dalam memahami konsep dengan baik dengan melakukan diskusi kelompok (Huda, 2015).

NHT (Number Head Together) adalah salah satu model pembelajaran yang menekankan pada struktur khusus yang dirancang untuk mempengaruhi pola interaksi siswa dan memiliki tujuan untuk meningkatkan penguasaan akademik (Fathurrohman, dkk, 2012).

Berdasarkan hasil wawancara yang telah dilakukan dengan salah satu guru fisika di SMA Negeri 11 Kendari mengenai keadaan sekolah secara umum dan kondisi pembelajaran fisika khususnya kelas X, kegiatan pembelajaran yang dilakukan masih berpusat pada guru sedangkan siswanya kurang aktif dalam pembelajaran dikelas. Hal ini disebabkan karena keterbatasan pemahaman guru dalam menerapkan metode pembalajaran. Oleh karena itu, hasil belajar siswa pada mata pelajaran fisika belum optimal, sebagian besar dari nilai ulangan siswamasih di bawah batas ketuntasan minimal (KKM) yakni 70.

Melihat keadaan tersebut, maka peneliti tertarik untuk menerapkan model pembelajaran koopertif CRH dan model kooperatif NHT, untuk meningkatkan kualitas dan efektivitas proses pembelajaran yang berlangsung di kelas.

\section{METODE PENELITIAN}

Jenis penelitian ini adalah penelitian quasi experimental design yaitu eksperimen semu dengan desain penelitian yang digunakan adalah Pre Experimental Design (Sugiyono 2014). Desain penelitian dapat dijelaskan pada tabel berikut:

Tabel 1. Desain Penelitian Eksperimen

\begin{tabular}{cccc}
\hline Kelompok & Pre-test & Treatmen & Post-test \\
\hline Eksperimen & $\mathrm{O}_{1}$ & $\mathrm{X}_{1}$ & $\mathrm{O}_{3}$ \\
\hline Kontrol & $\mathrm{O}_{2}$ & $\mathrm{X}_{2}$ & $\mathrm{O}_{4}$ \\
\hline
\end{tabular}

\section{Keterangan:}

$\mathrm{X}_{1}=$ Perlakuan Coure Review Horay

$\mathrm{X}_{2}=$ Perlakuan Number Head Together

$\mathrm{O}_{1}=$ Nilai kelas eksperimen sebelum diajar dengan model Course Review Horay

$\mathrm{O}_{2}=$ Nilai kelas eksperimen setelah diajar dengan model Course Review Horay

$\mathrm{O}_{3}=$ Nilai kelas kontrol sebelum diajar dengan model Number Head Together

$\mathrm{O}_{4}=$ Nilai kelas kontrol setelah diajar dengan model Number Head Together

Populasi penelitian ini yaitu siswa kelas X SMA Negeri 11 tahun ajaran 2019/2020 yang terdiri dari 4 kelas dengan jumlah siswa 136 siswa. Teknik pengambilan sampel ditentukan sejak awal atau tidak dilakukan randomisasi dengan teknik purposive sampling (Sugiyono, 2017, h. 67). Sampel penelitian ini yaitu kelas X MIPA 3 sebagai kelas kontrol terdiri dari 34 siswa dan kelas X MIPA 4 sebagai kelas eksperimen yang terdiri dari 35 siswa. Untuk pengumpulan data menggunakan observasi, tes pilihan ganda, dan dokumentasi. Sedangkan teknik analisis data yang digunakan adalah analisis statistik deskriptif dan analisis statistik inferensial, sedangkan teknik analisis data yang digunakan yaitu analisis statistik deskriptif dan analisis statistik inferensial.

Analisis statistika deskriptif, yaitu menghitung rata-rata, rentang data, jumlah kelas intrval,panjang kelas, variansi, standar deviasi, persentse dan kategori. Sedangkan analisis statistika inferensial diawali dengan melakukan uji persyaratan analisis, yaitu; uji normalitas, uji homogenitas, selanjutnya untukpengujian hipotesis digunakan $t$-test dengan membandingkan nilai thitung dan ttabel dengan taraf signifikansi $\alpha=5 \%$ dan uji Normal Gain.Selanjutnya melakukan interpretasi data dari hasil-hasil pengujian tersebut kemudian menarik kesimpulan pada hasil penelitian.

\section{HASIL PENELITIAN}

Deskripsi data dari hasil tes awal dan tes akhir pada kelas eksperimen dan kelas kontrol dapat dilihat pada tabel berikut: 
Tabel 2. Data Hasil Belajar Sebelum dan Sesudah Perlakuan pada kelas eksperimen dan kelas kontrol

\begin{tabular}{|c|c|c|c|c|}
\hline \multirow{3}{*}{ Statistik } & \multicolumn{4}{|c|}{ Nilai Hasil Belajar } \\
\hline & \multicolumn{2}{|c|}{ Kelas Eksperimen } & \multicolumn{2}{|c|}{ Kelas Kontrol } \\
\hline & Pre test & Post test & Pre test & Post test \\
\hline $\mathrm{N}$ & 30 & 30 & 26 & 26 \\
\hline Rata-Rata & 55,87 & 76,37 & 54,73 & 84,19 \\
\hline Nilai Terendah & 38 & 56 & 31 & 56 \\
\hline Nilai Tertinggi & 81 & 100 & 75 & 100 \\
\hline Varians & 107,48 & 138,61 & 153,40 & 111,74 \\
\hline Standar Deviasi & 10,37 & 11,77 & 12,36 & 10,53 \\
\hline
\end{tabular}

Sumber : Hasil Penelitian 2020

Berdasarkan tabel 2 di atas perolehan nilai rata-rata hasil belajar sebelum perlakuan pada kelas eksperimen yaitu 55,87 dan perolehan nilai rata-rata hasil belajar pada kelas kontrol yaitu 54,73, sehingga perolehan nilai rata-rata hasil belajar menunjukkan masih banyak yang nilai hasil belajarnya belum menenuhi KKM yang sudah ditentukan yaitu 70. Setelah diberikan perlakuan nilai rata-rata hasil belajar siswa pada kelas eksperimen yaitu 76,37 dan nilai rata-rata hasil belajar siswa pada kelas kontrol yaitu 84,19 .

Semua data terlebih dahulu dianalis dengan uji normalitas dan homogenitas data sehingga dapat ditentukan teknik pengujian statistik yang dilakukan. Pengolahan semua data menggunakan perhitungan secara manual. Berikut ini diuraikan analisis data hasil penelitian. 3 berikut.

Hasil uji normalitas hasil belajar pada kelas eksperimen dan kelas kontrol dapat dilihat pada tabel

Tabel 3.Hasil Uji Normalitas Kelas Eksperimen dan Kelas Kontrol

\begin{tabular}{|c|c|c|c|c|c|c|}
\hline Kelas & Perlakuan & $x_{\text {hitung }}^{2}$ & Dk & $x_{\text {tabel }}^{2}$ & $\alpha$ & Keterangan \\
\hline \multirow{2}{*}{ Eksperimen } & Pre test & 1,801 & \multirow{2}{*}{5} & \multirow{2}{*}{11,070} & \multirow{2}{*}{0,05} & Normal \\
\hline & Post Test & 9,674 & & & & Normal \\
\hline \multirow{2}{*}{ Kontrol } & Pre Test & 10,250 & \multirow{2}{*}{5} & \multirow{2}{*}{11,070} & \multirow{2}{*}{0,05} & Normal \\
\hline & Post Test & 6,798 & & & & Normal \\
\hline
\end{tabular}

Sumber: Hasil Penelitian 2020

Berdasarkan tabel 3. diatas terlihat bahwa pada kedua kelas memiliki $x^{2}{ }_{\text {hitung }}<x_{\text {tabel, }}^{2}$, berarti data berdistribusi normal.

Setelah uji normalitas dan diperoleh distribusi data yang normal selanjutnya adalah melakukan uji homogenitas. Setelah dilakukan pengolahan data dengan menggunakan uji $\mathrm{F}$ pada taraf signifikan $5 \%$, maka diperoleh nilai hitung uji homogenitas yang dapat dilihat pada tabel 4 Berikut.

Tabel 4.Uji Homogenitas Hasil Belajar Pre test dan Post test Kelas Eksperimen

\begin{tabular}{ccccccc}
\hline Kelas & $\boldsymbol{S}^{2}$ & $\boldsymbol{F}_{\text {hitung }}$ & $\boldsymbol{F}_{\text {tabel }}$ & $\boldsymbol{\alpha}$ & $\mathbf{d k}$ & Keterangan \\
\cline { 1 - 2 } Eksperimen & 113,02 & \multirow{2}{*}{1,49} & \multirow{2}{*}{1,90} & \multirow{2}{*}{0,05} & $\frac{30}{30}$ & \multirow{2}{*}{ Homogen } \\
\hline Kontrol & 168,76 & & & &
\end{tabular}

Sumber: Hasil Penelitian 2020

Berdasarkan tabel 4. Menunjukkan bahwa kedua kelas sampel memiliki $\mathrm{F}_{\text {hitung }}<\mathrm{F}_{\text {tabel, }}$ yang berarti data yang diperoleh memiliki varians yang homogen.

Berdasarkan hasil perhitungan uji normalitas dan uji homogenitas menunjukkan data berdistribusi normaldan memiliki varians yang homogen, sehingga untuk pengujian hipotesis digunakan uji t. hasil uji hipotesis dapat dilihat pada tabel 5 berikut.

Tabel 5.Hasil Uji Hipotesis

\begin{tabular}{cccc}
\hline Kelas & $\mathbf{t}_{\text {hitung }}$ & $\mathbf{t}_{\text {tabel }}$ & Keterangan \\
\hline Eksperimen & 2,67992 & 2,00488 & $\mathrm{H}_{0}$ Ditolak \\
\hline Kontrol & 2,692 & &
\end{tabular}

Berdasarkan hasil uji $\mathrm{t}$ didapatkan nilai $\mathrm{t}_{\text {hitung }}>\mathrm{t}_{\text {tabel }}$ atau 2,67992 $>2,00488$ maka $\mathrm{H}_{0}$ ditolak. Hal ini dapat dikatakan bahwa terdapat perbedaan hasil belajar fisika siswa pada materi hukum newton tentang gerak yang diajar menggunakan model CRH dan model NHT. 


\section{PEMBAHASAN}

Berdasarkan hasil analisis data deskriptif yaitu pada kelas eksperimen diperoleh rata-rata hasil belajar sebelum diajar dengan model CRH sebesar 55,87 dan rata-rata hasil belajar setelah diajar sebesar 76,3. Pada kelas kontrol diperoleh rata-rata hasil belajar sebelum diajar dengan model NHT sebesar 54,73 dan rata-rata hasil belajar setelah diajar sebesar 84,19. Jadi dapat disimpulkan bahwa setelah perlakuan, kedua kelas yang diteliti mengalami peningkatan nilai rata-rata. Meski demikian, model pembelajaran NHT yang digunakan pada kelas control menunjukkan peningkatan yang lebih signifikan, hal tersebut disebabkan karena model pembelajaran NHT memberikan kesempatan siswa untuk lebih banyak berfikir sendiri dan bekerja sama dengan siswa lainnya. Selain itu lebih banyak gagasan yang muncul, lebih banyak tugas yang dapat diberikan dan dapat mengembangkan kemampuan berkomunikasi dengan orang lain dalam mempelajari materi yang ditentukan. Serta siswa memiliki kesempatan untuk mendiskusikan gagasan mereka dan memberikan suatu pengertian bagi mereka untuk melihat cara lain dalam penyelesaian masalah. dengan demikian dapat memperluas dan memperdalam pengetahuan siswa.

Penelitian ini senada dengan yang dilakukan oleh (Simangungsong, dkk, 2020) dalam penelitiannya menyatakan bahwa penggunaan model NHT mampu meningkatkan hasil belajar siswa. Hal ini senada juga dengan penelitian yang dilakukan oleh (Fepti, 2018) dalam penelitiannya menyatakan bahwa penggunaan model NHT efektif dan meningkatkan hasil belajar siswa.

Hasil penelitian menunjukkan bahwa hasil belajar siswa sebelum menggunakan model CRH memiliki nilai terendah 38 dan nilai tertinggi 81 dengan nilai rata-rata hasil belajar fisika siswa sebelum menggunakan model CRH pada kelas eksperimen sebesar 55,87, sedangkan hasil belajar fisika siswa sebelum menggunakan model NHT memiliki nilai terendah 31 dan nilai tertinggi 75dengan nilai rata-rata hasil belajar fisika sebelum menggunakan model NHT pada kelas kotrol sebesar 54,73 sehingga dapat dijelaskan bahwa rata-rata hasil belajar fisika siswa sebelum diajar menggunakan model CRH pada kelas kontrol lebih tinggi dibanding nilai rata-rata hasil belajar fisika siswa sebelum diajar menggunakan model NHT pada kelas kontrol.

Berdasarkan hasil uji hipotesis diperoleh nilai $t_{\text {hitung }}$ lebih besar dari nilai $t_{\text {tabel }}$ sehingga dapat dinyatakan tidak terdapat perbedaan hasil belajar kognitif yang signifikan antara kelas ekperimen dan kelas kontrol sebelum diberi perlakuan. Dalam hal ini berarti kemampuan awal siswa sebelum diberikan perlakuan menunjukkan bahwa hasil belajar kognitif siswa pada kedua kelas memiliki kemampuan yang sama.Penelitian ini sesuai dengan penelitian yang dilakukan oleh (Widaningsih, \& Yenni, 2016) menyatakan bahwa pada uji hipotesis pre test diketahui bahwa kemampuan awal pemahaman siswa tidak terdapat perbedaan hasil belajar.

Hasil penelitian menunjukkan hasil belajar siswa pada kelas eksperimen dan kelas kontrol memiliki nilai terendah 56 dan nilai tertinggi 100 dengan rata-rata hasil belajar siswa pada kelas eksperimen yaitu 76,37 sedangkan pada kelas kontrol 84,19.

Dari hasil pengujian hipotesis menunjukkan bahwa thitung lebih besar dari ttabel maka dapat dijelaskan bahwa terdapat perbedaan yang signifikan pada hasil belajar kognitif siswa kelas eksperimen atau yang diberi perlakuan menggunakan model CRH dengan hasil belajar kognitif siswa kelas kontrol atau yang diberi perlakuan dengan model NHT.

Penelitian yang senada yang dilakukan oleh (Perdana, dkk, 2017) menyatakan bahwa penerapan model pembelajaran kooperatif tipe NHT berpengaruh signifikan terhadap peningkatan hasil belajar siswa. Hal ini sejalan dengan penelitian yang dilakukan oleh (Suryani Ulandari, 2019) menyatakan bahwa pembelajaran yang menggunakan model NHT dapat meningkatkan hasil belajar siswa.

Dengan demikian dapat disimpulkan bahwa model pembelajaran NHT lebih efektif digunakan pada mata pelajaran fisika dengan materi hukum newton tentang gerak dibanding model pembelajaran CRH, akan tetapi kedua model tersebut dapat meningkatkan hasil belajar kognitif siswa. Walaupun pada pertemuan awal siswa masih kelihatan kaku dalam belajar menggunakan model pembelajaran. Model pembelajaran yang bervariasi akan mampu mengembangkan potensi yang ada dalam diri siswa.

\section{KESIMPULAN} berikut:

Berdasarkan hasil penelitian dan pembahasan yang telah didapat maka diambil kesimpulan sebagai

1. Hasil belajar fisika sebelum diberikan perlakuan pada siswa kelas eksperimen dan kelas kontrol secara keseluruhan belum mencapai ketuntasan hasil belajar kognitif yaitu pada kelas eksperimen memperoleh nilai rata-rata hasil belajar fisika siswa sebesar 55,87 dan pada kelas kontrol memperoleh nilai rata-rata hasil belajar fisika siswa sebesar 54,73. Hasil belajar fisika siswa setelah diberikan perlakuan pada kelas eksperimen dan kelas kontrol secara keseluruhan tuntas dan terjadi peningkatan yaitu pada kelas eksperimen memperoleh rata-rata hasil belajar fisika sebesar 76,37 dan pada kelas kontrol memperoleh ratarata hasil belajar fisika sebesar 84,19 . 
2. Tidak ada perbedaan hasil belajar fisika sebelum menggunakan model CRH dan sebelum menggunakan model NHT pada siswa SMA Negeri 11 Kendari. Hal tersebut dibuktikan bahwa nilai thitung $=0,3638$ diterima karena nilai thitung lebih kecil dari nilai ttabel yaitu $0,3638<2,05488$ atau nilai $t \neg$ hitung lebih besar dari nilai -ttabel $\neg$ yaitu $0,3638>2,0488$. Hal ini dapat disimpulkan bahwa hasil belajar fisika sebelum menggunakan model CRH dan sebelum menggunakan model NHT sama atau homogen.

3. Terdapat perbedaan hasil belajar fisika setelah diberikan perlakuan pada siswa SMA Negeri 11 Kendari. Hal tersebut dibuktikan dari hasil pengolahan data diperoleh nilai thitung $>$ ttabel atau 2,661 $>2,00488$. Hal ini dapat simpulkan bahwa hasil belajar sesudah menggunakan model NHT lebih baik dibandingkan hasil belajar sesudah menggunakan model CRH, dan kedua model ini dapat meningkatkan hasil belajar siswa.

\section{DAFTAR PUSTAKA}

Engkoswara dan Aan Komariah. (2011). Administrasi Pendidikan. Bandung: Alfabeta.

Fathurroman, dkk. (2012). Belajar dan Pembelajaran: Meningkatkan Mutu Pembelajaran Sesuai Standar Nasional. Yogyakarta: Teras.

Huda, Miftahul. (2015). Model-Model Pengajaran dan Pembelajaran. Yogyakarta: Pustaka Pelajar.

Mutiara, Fepti Bunga. (2018). Efektivitas Model Kooperatif Tipe Course Review Horay (CRH) Terhadap Hasil Belajar Siswa dan Keterampilan Proses Sains (KPS) pada Kelas XI Di SMAN 9 Bandar Lampung. Skripsi Fakultas Tarbiyah dan keguruan UIN Raden Intan Lampung.

Perdana, I Putu Mandi, dkk. (2017). "Pengaruh Penerapan Model Pembelajaran Kooperatif Tipe Number Head Together Terhadap Hasil Belajar Teknik Dasar Passing Bola Voli”. Jurnal Pendidikan Jasmani, Kesehatan dan Rekreasi. Vol. 8 No. 2.

Simagungsong, Ika Trisni, dkk. (2020). "Pengaruh Model Pembelajaran Kooperatif NHT (Numbered Head Together) Berbantuan Mind Mapping Terhadap Hasil Belajar Fisika Pada Materi Pokok Listrik Dinamis". Jurnal Darma Agung. Vol. 28 No. 1.

Sugiyono. (2014). Metode Penelitian Pendidikan (Pendekatan Kuantitatif, Kualitatif, dan R\&D). Bandung: Alfabeta.

(2017). Statistika Untuk Penelitian. Bandung: Alfabeta.

Ulandari, Suryani. (2019). Pengaruh Model Number Head Together (NHT) Terhadap Hasil Belajar Siswa pada Materi Ekosistem Di Kelas X IPA SMA Negeri 11 Palembang. Skripsi Fakultas Keguruan dan Ilmu Pendidikan Universitas Muhammadiyah Palembang.

Widaningsih, N dan Yenni. (2016). "Perbandingan Kemampuan Pemahaman Matematis Siswa Antara Yang Mendapat Model Pembelajaran Course Review Horay dan Number Head Together”. Jurnal JPPM Vol. 9 No. 1 . 